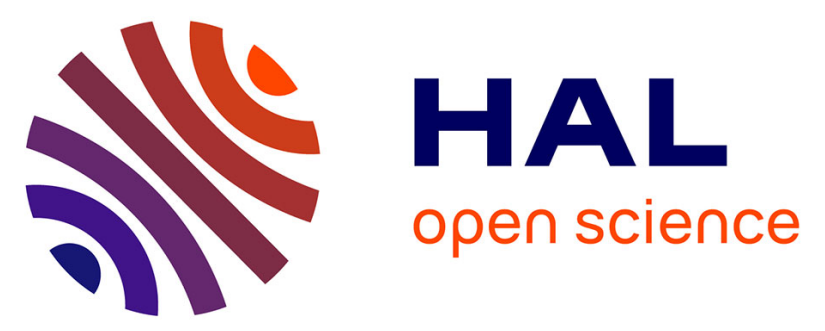

\title{
SOLEIL shining on the solution-state structure of biomacromolecules by synchrotron X-ray footprinting at the metrology beamline
}

\author{
Anna Baud, Laure Aymé, Florence Gonnet, Isabelle Salard, Yann Gohon, \\ Pascale Jolivet, Konstantin Brodolin, P. da Silva, Alexandre Giuliani, B. \\ Sclavi, et al.
}

\section{To cite this version:}

Anna Baud, Laure Aymé, Florence Gonnet, Isabelle Salard, Yann Gohon, et al.. SOLEIL shining on the solution-state structure of biomacromolecules by synchrotron X-ray footprinting at the metrology beamline. Journal of Synchrotron Radiation, 2017, 24, pp.576-585. 10.1107/S1600577517002478 . hal-01608337

\section{HAL Id: hal-01608337 https://hal.science/hal-01608337}

Submitted on 25 May 2020

HAL is a multi-disciplinary open access archive for the deposit and dissemination of scientific research documents, whether they are published or not. The documents may come from teaching and research institutions in France or abroad, or from public or private research centers.
L'archive ouverte pluridisciplinaire HAL, est destinée au dépôt et à la diffusion de documents scientifiques de niveau recherche, publiés ou non, émanant des établissements d'enseignement et de recherche français ou étrangers, des laboratoires publics ou privés. 


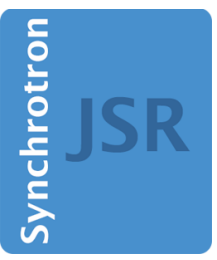

JOURNAL OF

SYNCHROTRON

RADIATION

Volume 24 (2017)

Supporting information for article:

SOLEIL SHINING ON THE SOLUTION-STATE STRUCTURE OF BIOMACROMOLECULES BY SYNCHROTRON X-RAY FOOTPRINTING AT THE METROLOGY BEAMLINE

A. Baud, L. Ayme, F. Gonnet, I. Salard, Y. Gohon, P. Jolivet, K. Brodolin, Paulo Da Silva, A. Giuliani, B. Sclavi, T. Chardot, P. Mercère, P. Roblin and R. Daniel 


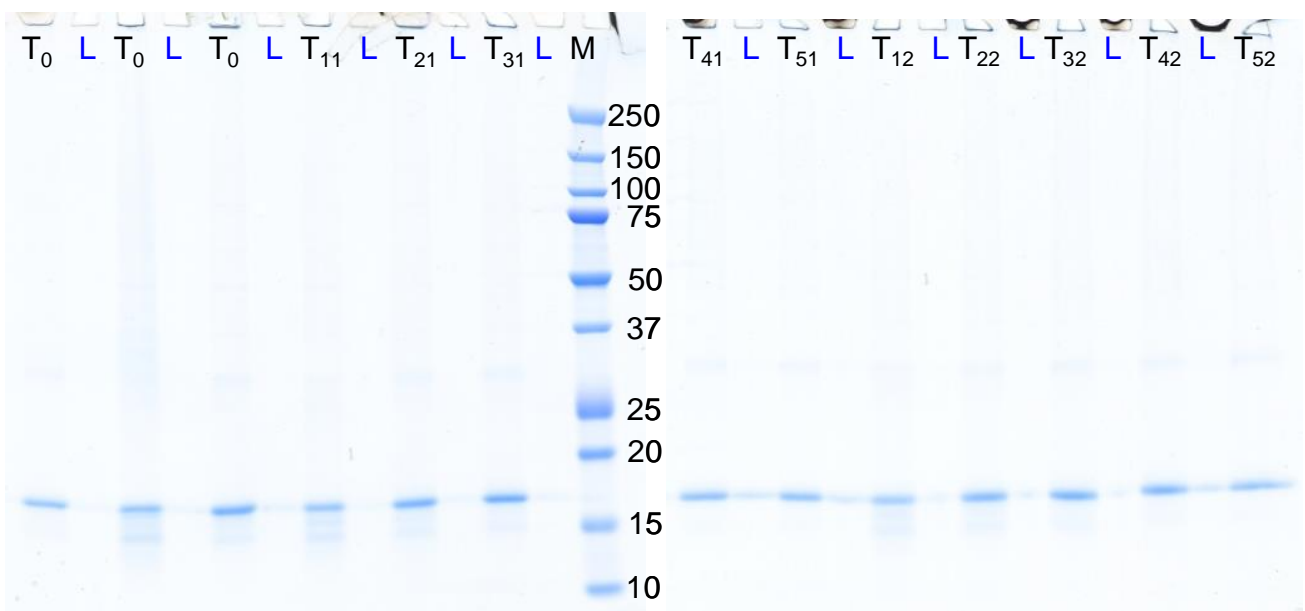

Figure S1 SDS-PAGE of oil bodies purified from S. cerevisiae expressing S3 oleosin and irradiated by X-ray beam from 0 to $100 \mathrm{~ms}$. Three non-irradiated samples (T0) were injected, followed by two series of irradiated samples (series $\mathrm{T}_{\mathrm{x} 1}$ and $\mathrm{T}_{\mathrm{x} 2}$ ) submitted to increasing irradiation time (2.5 ms [ $x=1]$; $10 \mathrm{~ms}[x=2]$; $25 \mathrm{~ms}$ [ $x=3]$; $50 \mathrm{~ms}[x=4]$; $100 \mathrm{~ms}[x=5])$. The intermediate washing fractions $(\mathrm{L})$ were also analyzed in order to check all collected fractions. 


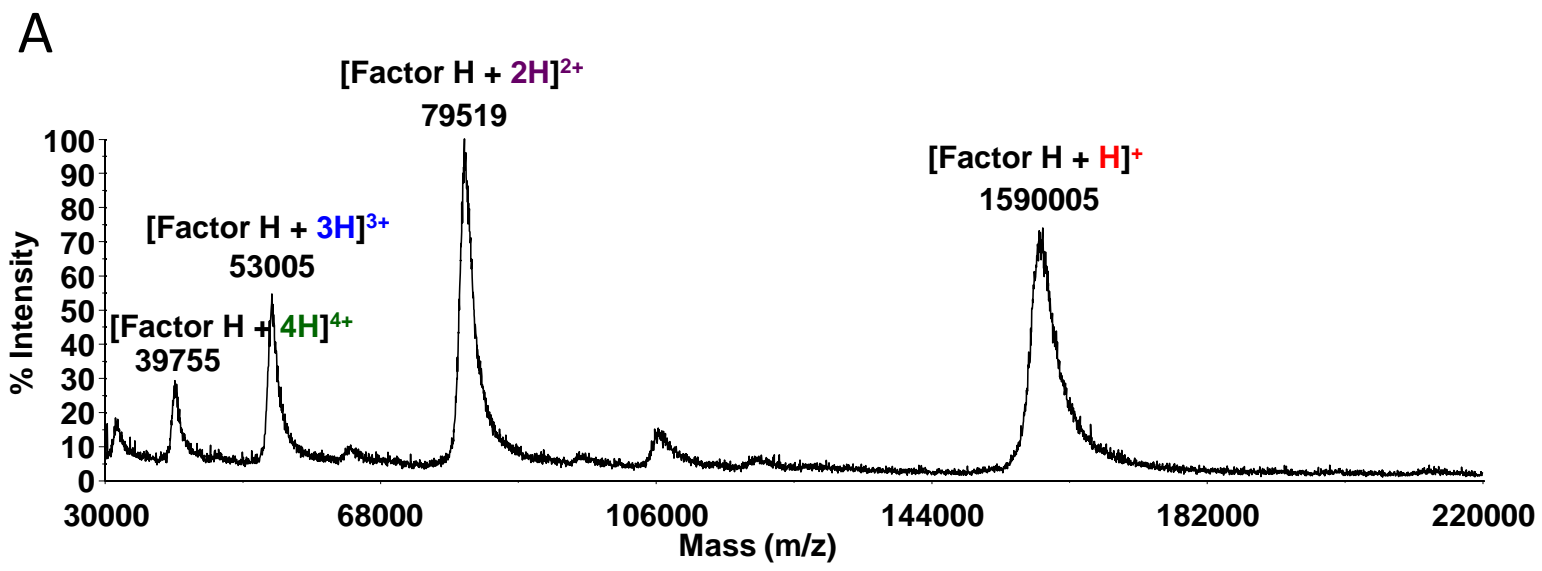

B

$[\text { Factor } \mathrm{H}+2 \mathrm{H}]^{2+}$

79494

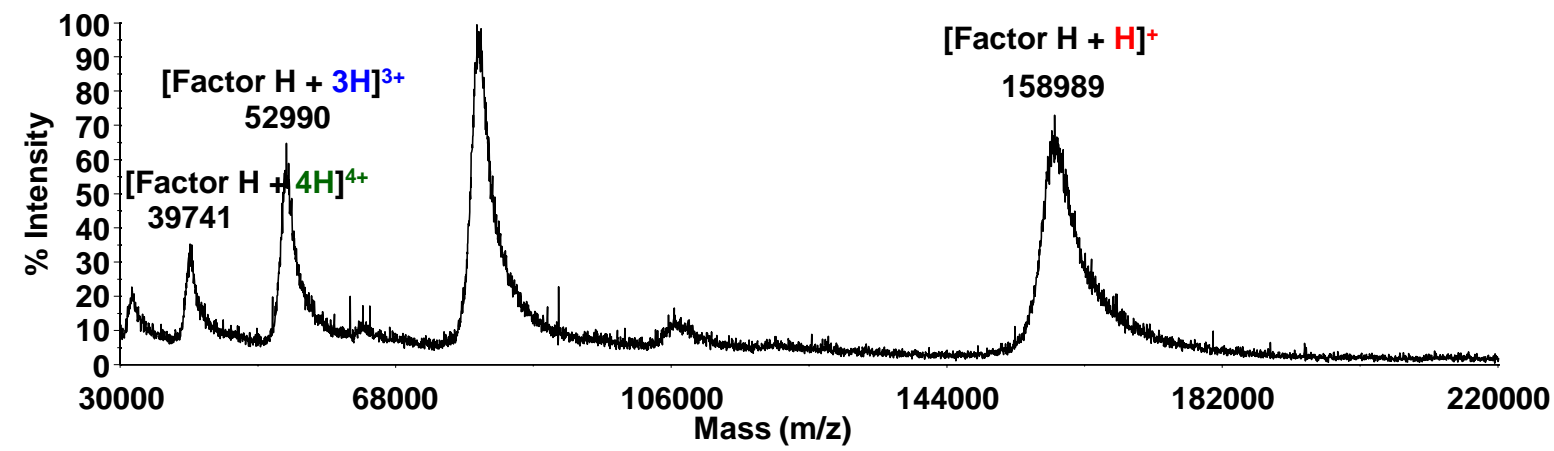

Figure S2 Mass spectrometry control of synchrotron-irradiated FH. Positive MALDI-TOF mass spectrum in linear mode of Factor H (2 pmol spotted) before (A) and after (B) synchrotron irradiation for $30 \mathrm{~ms}$. Please note that no mass shift of FH molecular weight was observed after the irradiation, confirming the integrity of the protein. Irradiation-specific mass shift could not be observed due to the low resolution of the MALDI-TOF MS. Matrix is 2,4,6-trihydroxyacetophenone (THAP) at $10 \mathrm{mg} / \mathrm{mL}$ in acetontrile/water (50:50 v/v) $0.1 \%$ trifluoroacetic acid. MALDI parameters: Voltage: $25 \mathrm{kV}$, grid \%: $70 \%$, extraction delay: $1000 \mathrm{~ns}$, laser attenuation $(\lambda=337 \mathrm{~nm}): 3400$ arbitrary units and 500 laser shots were averaged.

Table S1 Quantification of S3 oleosin bands from fig. S1 gel by using gel densitometry (MultiGauge software). Determined optical densities after background subtraction where normalized by the average intensity of the non-irradiated sample.

\begin{tabular}{|c|c|c|c|c|c|c|}
\hline $\begin{array}{c}\text { Irradiation time } \\
(\mathrm{ms})\end{array}$ & 0 & 2.5 & 10 & 25 & 50 & 100 \\
\hline $\begin{array}{c}\text { Relative S3 gel } \\
\text { band density }\end{array}$ & $100 \pm 21$ & $82 \pm 8$ & $118 \pm 13$ & $128 \pm 10$ & $106 \pm 11$ & $87 \pm 0.8$ \\
\hline
\end{tabular}

